\title{
Synthesis of $3,3^{\prime}$-bis(sulfonato) $-4,4^{\prime}-$ bis(chloroacetamido) azobenzene and cysteine cross-linking for photo-control of protein conformation and activity
}

\author{
Darcy C Burns ${ }^{1}$, Fuzhong Zhang² \& G Andrew Woolley ${ }^{2}$ \\ ${ }^{1}$ Worsfold Water Quality Centre, Trent University, 1600 West Bank Drive, Peterborough, ON, Canada K9J 7B8. ${ }^{2}$ Department of Chemistry, University of Toronto, 80 Saint \\ George Street, Toronto, ON, Canada M5S 3H6. Correspondence should be addressed to D.C.B. (darcyburns@trentu.ca) or G.A.W. (awoolley@chem.utoronto.ca). \\ Published online 8 March 2007; doi:10.1038/nprot.2007.21

\begin{abstract}
This protocol describes a procedure for the synthesis of $3,3^{\prime}$-bis(sulfonato) $-4,4^{\prime}$-bis (chloroacetamido) azobenzene (BSBCA), a watersoluble, thiol-reactive, photo-switchable cross-linker. In addition, a protocol is outlined for installing the cross-linker in an intramolecular fashion onto proteins bearing two surface-exposed Cys residues. BSBCA is designed to be used as an in vitro activity switch that operates by exerting temporal and reversible photo-control over $\alpha$-helix content within synthetic peptides and recombinant proteins. Synthesis of the cross-linker requires approximately $4.5 \mathrm{~d}$, and cross-linking can be performed in 10-12 h.
\end{abstract}

\section{INTRODUCTION}

The primary strategy for photo-regulation of biomolecular function using azobenzene is to change the host system by exploiting structural, electronic and volume changes that accompany a trans-to-cis azobenzene isomerization event. Examples of biomolecular systems into which azobenzene has been incorporated for photo-regulation are peptides ${ }^{1-3}$, enzymes ${ }^{4-7}$, oligonucleotides ${ }^{8,9}$ and ion channels ${ }^{10,11}$. Methods for incorporating azobenzene chromophores into biomolecules include solid-phase peptide or oligonucleotide synthesis ${ }^{7,12}$, nonsense suppression via azobenzenecharged suppressor tRNAs ${ }^{4}$, and both non-selective ${ }^{13}$ and targeted chemical modification of protein side chains ${ }^{14}$.

To be generally useful, azobenzene photo-switches intended to control protein activity should be incorporated under mild aqueous conditions and should target features that are common to all proteins. Ideally, one isomeric state of the chromophore locks the protein in an 'off' functional state, and in the other isomeric state the protein is in an 'on' state. The extent to which this is achieved depends critically on where the switch is placed and how well isomerization is coupled to protein conformational change. Incorrect placement can lead to inconsequential changes in conformation or to switches becoming locked in the cis or trans state ${ }^{15-17}$.

Chemical cross-linking is often employed as a way to introduce intramolecular bridges into peptides and proteins. Such bridges can be used to stabilize or alter protein structure, dynamics and function ${ }^{18,19}$. If the azobenzene chromophore is used as a component of these intramolecular bridges, photo-isomerization can be used to perturb the structure of the bridge reversibly, and thereby to alter key components of protein conformation. When properly targeted, these photo-switchable cross-linkers can be used to photo-control protein activity.

We have focused primarily on targeting the conformational control of helical structures using thiol-reactive, azobenzenebased photo-switchable cross-linkers ${ }^{3,16,20,21}$. As Cys residues can easily be introduced via site-directed mutagenesis, this azobenzenebased cross-linking strategy offers a fairly general way to photocontrol protein $\alpha$-helix content and thereby activity. We have reported on the design and synthesis of a number of different cross-linkers exhibiting a variety of properties ${ }^{3,21-23}$. Among the most generally useful of these is sodium $3,3^{\prime}$-bis(sulfonato)-4, $4^{\prime}$ bis(chloroacetamido)azobenzene (BSBCA), a fully water-soluble, thiol-reactive cross-linker that can be isomerized from trans to cis by irradiation at $370 \mathrm{~nm}$ and can be relaxed thermally from cis to trans with a half-life of approximately $20 \mathrm{~min}$ at room temperature $\left(20-24{ }^{\circ} \mathrm{C}\right)$.

Cross-linking reactions can be performed with BSBCA under mild conditions (room temperature, physiological $\mathrm{pH}$ and a completely aqueous environment). A variety of helical peptides and proteins bearing two Cys residues have been cross-linked, and their conformational and functional properties have been studied; these include the peptides JRK-7 and FK-11 and the proteins MyoD, engrailed and GCN4 $4^{27,29-31}$. Intermolecular cross-linking between proteins was not apparent in any of these cases and was likely suppressed by the fast intramolecular reaction between the chloroacetamide moiety of BSBCA and the second Cys residue. Photo-isomerization takes place rapidly, with high quantum yield, and occurs at wavelengths higher than $300 \mathrm{~nm}$, so the light used to produce isomerization is not strongly absorbed by protein and nucleic acid present in biological targets $7,24-26$.

Here, we present our approach to the synthesis of BSBCA (Fig. 1) and a protocol for its use in protein cross-linking. Although the cross-linking reactions are robust and provide a route toward installing structural and activity switches into proteins and peptides in general, the following considerations will determine whether a particular protein or peptide is compatible with this cross-linking strategy. (i) Two Cys residues are required for cross-linking BSBCA. These Cys residues can be site-specifically mutated into the protein or peptide sequence, ideally within the helical region, to facilitate cross-linking. Pro and Gly, which often play particular conformational roles, and residues that are directly involved in protein activity (e.g., an enzyme active site residue or DNA-binding residue) should not be replaced. (ii) For proteins, the two Cys residues should be positioned so that they are exposed to the bulk solvent. (iii) To date, the effects of BSBCA on helical structures alone have been characterized. When Cys residues spaced $i, i+4$ or $i$, 
$i+7$ are cross-linked, trans-to-cis isomerization of the linker can promote helix formation, but when Cys residues spaced $i, i+11$ are cross-linked, trans-to-cis isomerization of the linker inhibits helix formation ${ }^{27}$. The extent of regulation of the helix structure depends on the energetics and dynamics of conformational changes in each particular case. This issue is discussed further in a recent review ${ }^{17}$. (iv) Although the cross-linking reaction can be limited to predetermined sites in the presence of a wide variety of side-chain functionalities, any native Cys residues that are surface-accessible should be mutated to Ser or Ala to ensure that cross-linking occurs in a chemoselective fashion. (v) Cys-containing peptides and proteins should be protected from oxidation to avoid disulfide bond formation, refolding or misfolding events and aggregation. For this reason, and to preserve the nucleophilicity of its cysteinyl thiols, the protein or peptide must be maintained in its reduced form at slightly basic pH (Fig. 2).

If each of these points is taken into consideration, cross-linking should proceed smoothly with the intended goal of chemoselectivity. Cross-linking can be monitored by BSI-MS (Fig. 3) and isomerization can be assessed using UV-visible spectroscopy

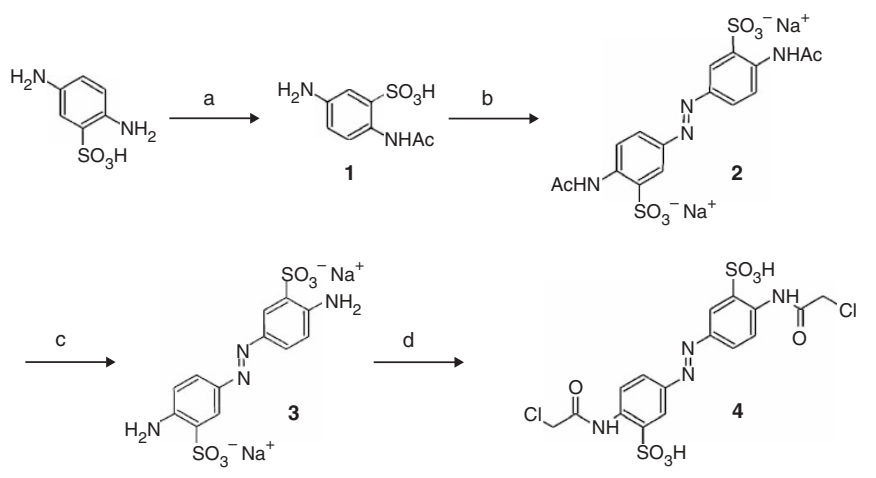

Figure 1 | Reaction scheme for the synthesis of 3,3'-bis(sulfonato)-4,4'bis(chloroacetamido)azobenzene (4). (a) Glacial acetic acid, acetic anhydride (1.2 eq.); (b) i. $\mathrm{H}_{2} \mathrm{O}$, sodium carbonate ii. sodium hypochlorite; (c) i. $\mathrm{H}_{2} \mathrm{O}, \mathrm{HCl}$ ii. $\mathrm{NaOH}$; (d) chloroacetic acid (24 eq.), chloroacetic anhydride (24 eq.).

(Fig. 4) and helix-coil switching can be assessed using CD spectroscopy (Fig. 5). Activity tests should be designed according to the protein or peptide under investigation.

\section{MATERIALS}

\section{REAGENTS}

-2,5-Diaminobenzenesulfonic acid (Sigma-Aldrich, cat. no. 32776)

- Glacial acetic acid (Sigma-Aldrich, cat. no. 537020) I CAUTION Flammable and corrosive; handle only in a vented fumehood

- Acetic anhydride (Sigma-Aldrich, cat. no. 242845) ! CAUTION Flammable, corrosive and toxic by inhalation; it also reacts violently with water and should be handled only in a vented fumehood

- Sodium carbonate (Sigma-Aldrich, cat. no. 223530) (see REAGENT SETUP)

- Sodium hypochlorite (Sigma-Aldrich, cat. no. 425044) I CAUTION Corrosive acid; handle only in a vented fumehood

- $\mathrm{NaOH}$ (Sigma-Aldrich, cat. no. 221465) (see REAGENT SETUP)

- Chloroacetic acid (Sigma-Aldrich, cat. no. 402923) I CAUTION Chloroacetic acid is highly toxic and corrosive; avoid inhalation and contact with skin; handle only in a vented fumehood

- Chloroacetic anhydride (Sigma-Aldrich, cat. no. 215163) ! CAUTION Toxic and readily absorbed through the skin; handle only in a vented fumehood

- Tris-HCl buffer (see REAGENT SETUP)

$\cdot \mathrm{HCl}$

- Tris-(2-carboxyethyl)phosphine hydrochloride (TCEP) (Sigma-Aldrich, cat. no. 93284)

-Dichloromethane ! CAUTION Dichloromethane is a toxic carcinogen; handle only in a vented fumehood

- Ethanol ! CAUTION Ethonol is highly flammable; handle only in a vented fumehood

- Ice

- Sodium phosphate buffer

EQUIPMENT

$\cdot 2 \times 50-\mathrm{ml}$ round-bottom flask

$\cdot 2 \times 10-\mathrm{ml}$ round-bottom flask

$\cdot 1 \times 5$-ml round-bottom flask

$\cdot 3 \times$ white rubber septum (Sigma-Aldrich, cat. no. Z100749)

- Magnetic heat plate with digital thermometer and probe (RET digi-visc,

IKA Labortechnic)

- Condenser and tubing for reflux

- Heat bath oil

$\cdot 2 \times$ large glass dewar dish

- Plastic syringes (Henke Sass Wolf GmbH)

-20-gauge 1.5-inch disposable syringe needles (Becton Dickinson)

- P8, qualitative, coarse filter paper (Fisherbrand, cat. no. 09-795B)

- Ceramic Hirsch funnel and vacuum tubing

- Rotary evaporator (Buchi)

- Vacuum pump

- $\mathrm{pH}$ meter and probe (Radiometer, Copenhagen)

- Balloon affixed to a 3-ml plastic syringe cut flush at 1-ml mark

- Centrifugal filter tube (Amicon Ultra-15, Millipore)

- Sorvall Legend T/RT, with Rectangular bucket $250 \mathrm{ml}$ rotor

- Nitrogen gas

- $70 \mathrm{~W}$ metal halide Tri-Lite lamp (World Precision Instruments)

$\cdot 370 \pm 10 \mathrm{~nm}$ band-pass filter (Harvard Apparatus, Canada)

REAGENT SETUP

0.1 M sodium carbonate Dissolve $530 \mathrm{mg}$ sodium carbonate in $50 \mathrm{ml} \mathrm{H} \mathrm{H}_{2} \mathrm{O}$. 0.1 M sodium hydroxide Dissolve $200 \mathrm{mg}$ sodium hydroxide in $50 \mathrm{ml} \mathrm{H}_{2} \mathrm{O}$. $500 \mathbf{~ m M}$ Tris-HCl buffer (pH 8.5) Dissolve $60.57 \mathrm{~g}$ Tris base in $900 \mathrm{ml}$ $\mathrm{H}_{2} \mathrm{O}$. Adjust the $\mathrm{pH}$ of this solution to 8.5 by adding approximately $14.8 \mathrm{ml} 6 \mathrm{~N}$ $\mathrm{HCl}$. Fill with $\mathrm{dH}_{2} \mathrm{O}$ up to 11 .

\section{PROCEDURE}

\section{Synthesis of 2-acetylamino-5- aminobenzenesulfonic acid (1) TIMING $\mathbf{4}$ h $\mathbf{4 0}$ min}

1) Weigh $6.47 \mathrm{~g}(34.4 \mathrm{mmol}, 1.0$ eq.) 2,5-diaminobenzenesulfonic acid into a $100-\mathrm{ml}$ round-bottom flask containing a magnetic stir bar.

2| Add $50 \mathrm{ml}$ glacial acetic acid to the reaction vessel and seal the flask with a white rubber septum.
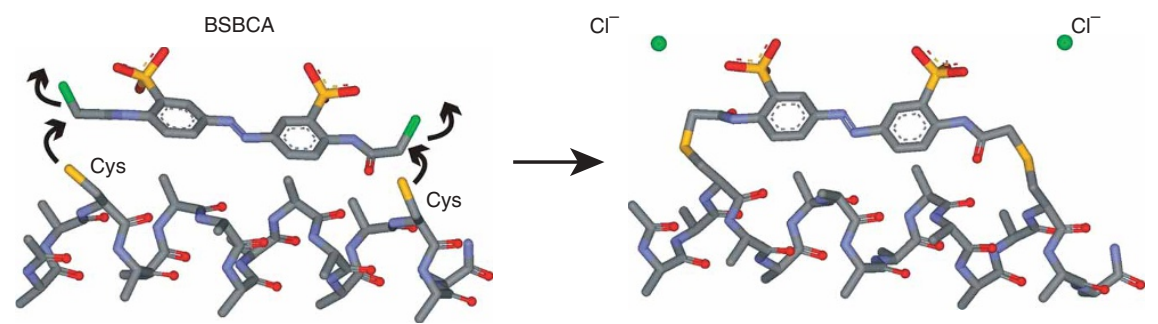

Figure 2 | Reaction scheme for intramolecular cross-linking between BSBCA and a double-Cys-containing helix (color coding is gray for carbon, blue for nitrogen, red for oxygen, yellow for sulfur and green for chlorine). 
3| Immerse the reaction flask in an oil bath (dewar dish) and heat to $94^{\circ} \mathrm{C}$ while stirring the contents using a magnetic heat plate.

4| Dispense $4.0 \mathrm{ml}$ acetic anhydride (42.4 mmol, 1.23 eq.) into the flask dropwise over 5 min using a 20-gauge 1.5-inch disposable needle and plastic syringe.

5| Stir this reaction mixture continuously for $2 \mathrm{~h}$ at $94^{\circ} \mathrm{C}$.

6| Remove the reaction flask from the hot oil bath and allow its contents to cool to room temperature (approximately $10 \mathrm{~min})$.

7| Filter the mixture through P8, qualitative, coarse filter paper using a Hirsch funnel under aspirator vacuum.

8| Rinse the reaction flask $(3 \times 3 \mathrm{ml})$ with hot acetic anhydride and use this solution to wash the filtered precipitate.

9| Collect the 2-acetylamino-5-aminobenzenesulfonic acid precipitate from Step 7 into a clean round-bottom flask and dry using a vacuum pump $(0.1-0.5 \mathrm{~mm} \mathrm{Hg})$.

- PAUSE POINT 2-Acetylamino-5-aminobenzenesulfonic acid should be left under vacuum for a minimum of $2 \mathrm{~h}$ to remove residual acidic solvent; however, it can then be stored in a sealed glass vial and left refrigerated indefinitely. We have not observed significant decomposition of this sample even after 1 year in a refrigerator.

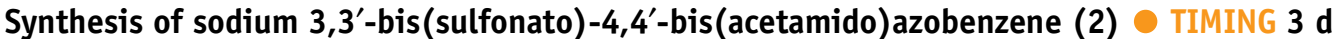

10| Dissolve 2-acetylamino-5-aminobenzenesulfonic acid $(1.725 \mathrm{~g}, 7.0 \mathrm{mmol})$ in $\mathrm{H}_{2} \mathrm{O}(18 \mathrm{ml})$ in a 50 - $\mathrm{ml}$ round-bottom flask containing a magnetic stir bar.

11. Adjust the $\mathrm{pH}$ of the 2-acetylamino-5-aminobenzenesulfonic acid solution to 8.5 by adding $0.1 \mathrm{M}$ sodium carbonate dropwise. The solution should change color from light pink to brown.

$\triangle$ CRITICAL STEP The pH must be adjusted to slightly basic to facilitate amine oxidation. If the pH is not properly adjusted, the yield will be significantly lowered.

12| Seal the reaction flask with a white rubber septum and immerse it in a $-5{ }^{\circ} \mathrm{C}$ bath: ice/brine (saturated $\mathrm{NaCl}$ ) solution contained in a glass dewar.

13| Dispense $19 \mathrm{ml}$ sodium hypochlorite solution (neat, as supplied by vendor) into the reaction flask dropwise over 5 min using a 20-gauge 1.5-inch disposable needle and plastic syringe.

14| Continue stirring the reaction mixture for $2 \mathrm{~h}$. It is necessary to add ice to the low-temperature bath to maintain the temperature at $-5{ }^{\circ} \mathrm{C}$.

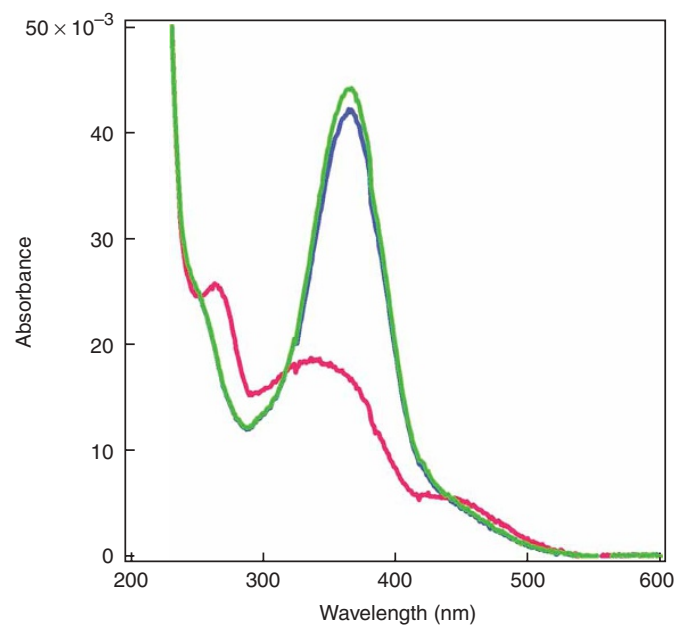

15 Wrap the reaction flask in aluminum foil and incubate at $4{ }^{\circ} \mathrm{C}$ for $3 \mathrm{~d}$.

- PAUSE POINT To maximize azobenzene yield, the 2-acetylamino-5-aminobenzenesulfonic acid reaction mixture can be stored in situ at $4{ }^{\circ} \mathrm{C}$ for up to $3 \mathrm{~d}$.

$\triangle$ CRITICAL STEP Be sure to perform the oxidation in the dark and keep subsequent reaction mixtures and products away from

Figure 4 | UV-visible spectra of dark-adapted (blue line), after irradiation at $370 \mathrm{~nm}$ (red line) and thermally recovered (green line) GCN4-bZIP protein. In this example, the Cys residues are spaced $i, i+7$ in a helical segment. Trans-tocis isomerization of the azobenzene chromophore is evidenced by a loss in absorbance at $363 \mathrm{~nm}$ along with a concomitant slight increase in absorbance at $450 \mathrm{~nm}$. Solution conditions: $10 \mathrm{mM}$ phosphate buffer ( $\mathrm{pH} 7.0$ ), $50 \mathrm{mM}$ $\mathrm{NaCl}$ at $10 \pm 1{ }^{\circ} \mathrm{C}$ at a protein concentration of $2 \mu \mathrm{M}$ (adapted with permission from ref. 29). 
Figure 5 | CD spectra of dark-adapted (blue line), after irradiation at $370 \mathrm{~nm}$ (red line) and thermally recovered (green line) GCN4-bZIP protein. In this example, the Cys residues are spaced $i, i+7$ in a helical segment. Trans-to-cis isomerization increases helical content as judged by the stronger ellipticity at $222 \mathrm{~nm}$. Solution conditions: $10 \mathrm{mM}$ phosphate buffer $\mathrm{pH} 7.0,50 \mathrm{mM} \mathrm{NaCl}$ at $10 \pm 1{ }^{\circ} \mathrm{C}$ at a protein concentration of $20 \mu \mathrm{M}$ (adapted with permission from ref. 29).

direct exposure to light; exposure to light may lead to decomposition of the azobenzene chromophore, particularly at elevated temperatures or $\mathrm{pHs}$.

16| Filter the mixture through P8, qualitative, coarse filter paper using a Hirsch funnel under aspirator vacuum.

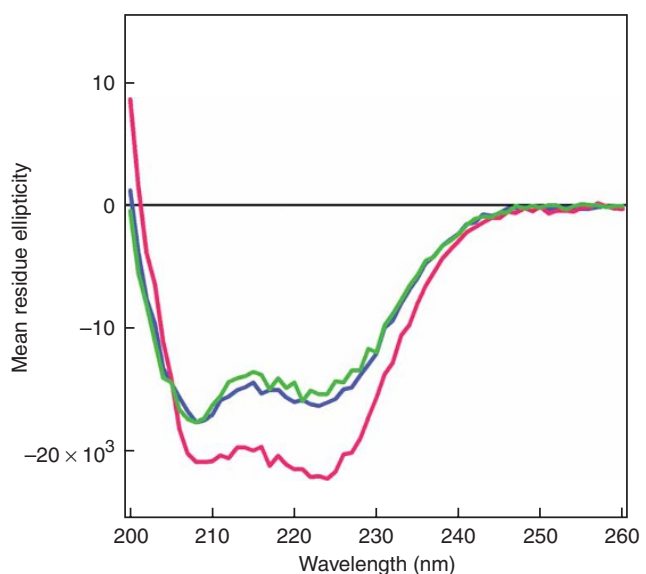

17| Wash filtered material with hot ethanol to yield pure sodium 3,3'-bis(sulfonato)-4,4'-bis(acetamido)azobenzene.

PAUSE POINT Pure sodium 3, $3^{\prime}$-bis(sulfonato)-4, $4^{\prime}$-bis(acetamido)azobenzene can be stored in a sealed glass vial and left refrigerated indefinitely. We have not observed significant decomposition of this sample even after 1 year in a refrigerator.

\section{Synthesis of sodium 3,3'-bis(sulfonato)-4,4'-bis(amino)azobenzene (3) $\bigcirc$ TIMING 15 h 30 min}

18| Add sodium 3,3'-bis(sulfonato)-4, $4^{\prime}$-bis(acetamido)azobenzene $\left(82.3 \mathrm{mg}, 0.18 \mathrm{mmol}\right.$ ) and $\mathrm{ddH}_{2} \mathrm{O}(2.75 \mathrm{ml})$ to a $10-\mathrm{ml}$ round-bottom flask containing a magnetic stir bar.

19| Add hydrochloric acid (ACS Reagent, 37\%, $0.55 \mathrm{ml}$ ) to this reaction mixture, immerse the reaction flask in an oil bath (dewar dish) and reflux, while stirring at $110{ }^{\circ} \mathrm{C}$ for $2.5 \mathrm{~h}$.

20| Cool the reaction mixture to room temperature and remove aqueous solvents using a rotary evaporator under aspirator vacuum.

21 Redissolve solid 3,3'-bis(sulfonato)-4,4'-bis(amino)azobenzene in $\mathrm{H}_{2} \mathrm{O}(8.0 \mathrm{ml}$ ) and adjust the $\mathrm{pH}$ of this solution to 8.5 by dropwise addition of $0.1 \mathrm{M} \mathrm{NaOH}$.

22 Lyophilize the sodium 3,3'-bis(sulfonato)-4,4'-bis(amino)azobenzene solution in a 50-ml round-bottom flask and dry the solution overnight using a vacuum pump $(0.1-0.5 \mathrm{~mm} \mathrm{Hg})$.

- PAUSE POINT Pure sodium 3,3'-bis(sulfonato)-4,4'-bis(amino)azobenzene can be stored in a sealed glass vial and left refrigerated indefinitely. We have not observed significant decomposition of this sample even after 1 year in a refrigerator.

\section{Synthesis of BSBCA (4) TIMING $13 \mathrm{~h}$}

23| Add sodium 3,3'-bis(sulfonato)-4,4'-bis(amino)azobenzene (30 mg, $0.081 \mathrm{mmol}$ ), chloroacetic acid (191 mg, $2.03 \mathrm{mmol}$, 25 eq.) and chloroacetic anhydride $(346 \mathrm{mg}, 2.03 \mathrm{mmol}, 25$ eq.) to a $10-\mathrm{ml}$ round-bottom flask containing a magnetic stir bar and seal the contents with a white rubber septum.

24| Immerse the reaction mixture in an oil bath, heat to $87^{\circ} \mathrm{C}$ and stir continuously for $9 \mathrm{~h}$. The melting points of chloroacetic acid and chloroacetic anhydride are $60-63$ and $48-60{ }^{\circ} \mathrm{C}$, respectively. Heating this reaction mixture will bring sodium 3, $3^{\prime}$-bis(sulfonato)-4, '4'-bis(amino)azobenzene into solution.

PAUSE POINT Although the sodium 3,3'-bis(sulfonato)-4, $4^{\prime}$-bis(amino)azobenzene mixture should be allowed to react for at least $9 \mathrm{~h}$, we have found that it can be left stirring overnight (approximately $12-15 \mathrm{~h}$ ) at $87^{\circ} \mathrm{C}$. In this case, neither the yield nor the purity of the final product is adversely affected.

25 Remove the reaction mixture carefully from the hot oil bath, allow it to cool to room temperature (approximately $15 \mathrm{~min}$ ) and continue to cool the reaction mixture over ice for an additional $30 \mathrm{~min}$ to precipitate BSBCA.

26| The round-bottom flask will contain BSBCA as well as unreacted chloroacetic anhydride and chloroacetic acid. Wash these materials from the reaction vessel using excess dichloromethane $(3-5 \times 5 \mathrm{ml})$ and filter the mixture through P8, qualitative, coarse filter paper using a Hirsch funnel under aspirator vacuum.

27| Collect the filtered precipitate BSBCA in a clean 5-ml round-bottom flask and dry using a 0.1-0.5 mm Hg vacuum pump. - PAUSE POINT Pure BSBCA should be left under vacuum for a minimum of $2 \mathrm{~h}$ to remove residual solvent; however, it can then be stored in a sealed glass vial and left refrigerated indefinitely. We have not observed significant decomposition of this sample even after 1 year in a refrigerator. 


\section{Protein cross-linking with BSBCA $\bigcirc$ TIMING Approximately $12 \mathrm{~h}$}

28| Transfer $5 \mathrm{ml} 100 \mu \mathrm{M}$ double-Cys mutant protein (500 nmol) to a centrifugal filter tube (Millipore, Amicon Ultra-15) and centrifuge at 4,000 r.p.m. at $4{ }^{\circ} \mathrm{C}$ for $30 \mathrm{~min}$ until a final volume of $500 \mu \mathrm{l}$ is reached. A Sorvall legend T/RT, with a 250-mL rectangular swinging bucket rotor, is suitable.

$\triangle$ CRITICAL STEP Centrifugal filter tubes offer a convenient means to concentrate and purify proteins and peptides. The protein solution should be pre-concentrated to improve rates of reaction in cross-linking with BSBCA.

? TROUBLESHOOTING

29| Add $50 \mathrm{mM}$ Tris- $\mathrm{HCl}$ buffer (pH 8.5) to the centrifugal filter tube up to $5 \mathrm{ml}$ and repeat centrifugation (4,000 r.p.m., $4{ }^{\circ}$, $30 \mathrm{~min}$ ) at least three times to ensure buffer exchange.

$\triangle$ CRITICAL STEP The final protein concentration should be no less than $1 \mathrm{mM}$ (centrifugation should proceed until $500 \mu \mathrm{l}$ solution remains).

30| Fit a $5 \mathrm{ml}$-round-bottom flask containing a magnetic stir bar with a white rubber septum. Insert a nitrogen inlet and vent consisting of disposable syringe needles and blow nitrogen gas through the flask for 2 min to purge oxygen from the flask.

31 Attach an empty balloon to the end of a 3-ml plastic syringe that has been cut flush at the $1 \mathrm{ml}$ mark (the balloon can be held in place with rubber bands). Fill the balloon with nitrogen gas and affix a 20-gauge 1.5-inch needle (Becton Dickinson) to the syringe. Insert this needle into the white rubber septum to maintain positive nitrogen pressure in the flask.

32| Using a disposable plastic syringe and needle, transfer the protein (500 $\mu \mathrm{l})$ from the centrifugal filter tube to the round-bottom flask.

33| Using a disposable plastic syringe and needle, dispense $10 \mu \mathrm{l} 500 \mathrm{mM}$ TCEP into the reaction flask (final TCEP concentration is $10 \mathrm{mM}$ ) and stir at room temperature for $30 \mathrm{~min}$.

$\triangle$ CRITICAL STEP Efficient protein cross-linking with BSBCA requires the reaction to be performed in the presence of a suitable reducing agent under nitrogen atmosphere. These measures help to prevent cysteinyl disulfide bond formation, an undesirable side reaction that inhibits protein cross-linking. TCEP, as a reducing agent, is found to be relatively unreactive toward the azobenzene moiety during protein cross-linking (D.C.B., Z.Z. and G.A.W., unpublished results) and should be used in preference to dithiothreitol, mercaptoethanol or any other sulfhydryl-based reducing agents. Commercially available TCEP is usually provided as a free acid and should be pre-buffered with $50 \mathrm{mM}$ Tris- $\mathrm{HCl}$ to maintain the protein cross-linking reaction at pH 8.5. TCEP solutions ( $0.5 \mathrm{M}$; $71.65 \mathrm{mg}$ TCEP in $0.5 \mathrm{ml} 50 \mathrm{mM}$ Tris- $\mathrm{HCl}$ ) should be prepared fresh and maintained at $2-8{ }^{\circ} \mathrm{C}$ before use in cross-linking.

34| Add 3,3'-bis(sulfonato)-4,4'-bis(chloroacetamido)azobenzene (4) $(1.3 \mathrm{mg}, 2.55 \mu \mathrm{mol}, 5.1 \mathrm{eq}$.) to the reaction mixture so that the final concentration is $5 \mathrm{mM}$. Immerse the reaction flask in an oil bath (dewar dish) and heat to $10{ }^{\circ} \mathrm{C}$ below the expected melting temperature of the protein so that it is maintained in a folded, functional state. Stir the reaction mixture continuously for $6 \mathrm{~h}$.

35 Transfer the reaction mixture to a centrifugal filter tube and centrifuge at 4,000 r.p.m. at $4{ }^{\circ} \mathrm{C}$ for 30 min until a final volume of $500 \mu \mathrm{l}$ is reached. Dilute the sample with $50 \mathrm{mM}$ Tris- $\mathrm{HCl}$ buffer (pH 8.5) to $5 \mathrm{ml}$ and repeat centrifugation at least three times to make sure that no free cross-linker remains (i.e., the filtrate has no color).

36 Check the completion of the reaction using UV spectroscopy by comparing $A_{280}$ and $A_{363}$. The cross-linker has molar extinction coefficients of 2,500 M-1 $\mathrm{cm}^{-1}$ at $280 \mathrm{~nm}$ and $24,000 \mathrm{M}^{-1} \mathrm{~cm}^{-1}$ at $363 \mathrm{~nm}$. The molar extinction coefficient at $280 \mathrm{~nm}$ of the un-cross-linked protein can be calculated using the Protein Parameter tool of the Expasy server (http://ca.expasy.org/tools/ protparam.html) ${ }^{28}$. The calculated value should be added to the value for the cross-linker. If cross-linking is complete, the ratio of $A_{280}$ to $A_{363}$ should equal the ratio of extinction coefficients: $\left(\alpha_{280}\right.$ (protein) $+\alpha_{280}($ linker $\left.)\right) /\left(\alpha_{363}(\right.$ linker $\left.)\right)$.

37| Check the completion of the reaction and integrity of the protein using MALDI or electrospray mass spectrometry. The cross-linker adds $452.5 \mathrm{Da}$ to the protein's mass.

$\triangle$ CRITICAL STEP Depending on the protein, up to three rounds of cross-linking may be required to acheive more than $98 \%$ cross-linking. In cases where additional rounds of cross-linking are necessary, Steps 28-36 should be repeated.

? TROUBLESHOOTING

\section{Preparation of cross-linked protein samples for UV-visible and CD spectroscopy $\bigcirc$ TIMING Approximately 1-2 $\mathbf{~}$}

38| Dissolve samples for UV and CD analyses in 5-50 mM sodium phosphate buffer, pH 7.0, at a concentration from 1 to $50 \mu \mathrm{M}$ depending on the cuvette to be used (typically $1 \mathrm{~cm}$ pathlength for UV and $0.1 \mathrm{~cm}$ pathlength for CD). Obtain spectra by following the manufacturer's instructions.

$\triangle$ CRITICAL STEP Irradiation of the sample to promote trans-to-cis photo-isomerization can be accomplished using a variety of light sources. For instance, a $70 \mathrm{~W}$ metal halide Tri-Lite lamp (World Precision Instruments) coupled to a $370 \pm 10 \mathrm{~nm}$ band-pass filter (Harvard Apparatus, Canada) and placed in front of a cuvette containing cross-linker protein will produce a photo-stationary state 
PROTOCOL

with approximately $80 \pm 10 \%$ cis isomer in 2-5 min at room temperature. Rapid cis-to-trans photo-isomerization can be accomplished using the same light source coupled to a $450 \mathrm{~nm}$ band-pass filter to produce $95 \%$ trans isomer within $1 \mathrm{~min}$. ? TROUBLESHOOTING

39| Measure the half-life for thermal relaxation back to the trans isomer by recording $A_{363}$ over time.

$\triangle$ CRITICAL STEP It is important to ensure that the spectrometer measuring beam is sufficiently weak that it does not perturb the rate of relaxation. This can be tested by placing a neutral density filter (e.g., Thorlabs NE02B unmounted $\varnothing 1^{\prime \prime}$ Absorptive ND Filter; optical density 0.2 ) in the path of the beam and testing for any effect on the measured decay rate.

\section{TIMING}

Steps 1-4: 15 min; Step 5: 2 h; Step 6: 10 min; Steps 7-8: 15 min; Step 9: 2-3 h; Steps 10-12: 15 min; Step 13: 5 min; Step 14: 2 h; Step 15: 3 d; Steps 16-17: 15 min; Step 18: 15 min; Step 19: 2.5 h; Steps 20-21: 30 min; Step 22: 12 h; Step 23: 15 min; Step 24: 9 h; Steps 25-26: 45 min; Step 27: 2-3 h; Steps 28-29: 2 h 15 min; Steps 30-33: 45 min; Step 34: 6 h; Step 35: 2 h 15 min; Steps 36-37: 30 min; Steps 38-39: 1-2 h

\section{? TROUBLESHOOTING}

Troubleshooting advice can be found in Table 1.

TABLE 1 | Troubleshooting table.

\begin{tabular}{|c|c|c|c|}
\hline Step & Problem & Possible reasons & Solution \\
\hline 28 & $\begin{array}{l}\text { Quantity of available protein is limited to } \\
\text { less than } 500 \mathrm{nmol}\end{array}$ & & $\begin{array}{l}\text { The reaction may be scaled down linearly } \\
\text { with respect to cross-linker ( } 5.1 \text { eq.), } \\
\text { protein ( } 1.0 \text { eq.) and TCEP ( } 10.2 \text { eq.) }\end{array}$ \\
\hline 37 & $\begin{array}{l}\text { No ESMS } m / z \text { signal for un-cross-linked } \\
\text { or cross-linked protein following the } \\
\text { cross-linking reaction }\end{array}$ & $\begin{array}{l}\text { Loss of protein during purification and } \\
\text { pre-concentration }\end{array}$ & $\begin{array}{l}\text { It may be necessary to pre-concentrate and } \\
\text { purify smaller peptides/proteins using a } \\
\text { centrifugal filter with lower nominal } \\
\text { molecular weight cut-off }\end{array}$ \\
\hline 37 & $\begin{array}{l}\text { Intense ESMS } m / z \text { signal for un-cross- } \\
\text { linked protein following the cross-linking } \\
\text { procedure }\end{array}$ & $\begin{array}{l}\text { Limited cysteinyl thiol reactivity } \\
\text { TCEP is not fresh }\end{array}$ & $\begin{array}{l}\text { Check that the cross-linker reaction has been } \\
\text { maintained at pH } 8.5 \text { and repeat protein } \\
\text { cross-linking Steps } 28-36 \text { again } \\
\text { Prepare prebuffered TCEP solution using } \\
\text { newly purchased TCEP }\end{array}$ \\
\hline
\end{tabular}

37 ESMS or MALDI-MS exhibits multiple peaks corresponding to protein fragments ESMS or MALDI-MS $m / z$ signal is more than twice that of cross-linked protein lowing irradiation of cross-linked protein

Protein degradation by active proteases in protein stock solution

A significant fraction of the protein has been cross-linked intermolecularly

Improperly functioning light source
Re-purify protein; add protease inhibitors

Repeat Steps 28-36

Repeat Steps 28-36 at reduced protein concentration

Acquire the light-adapted and dark-adapted UV-visible spectra of BSBCA under the same conditions as BSBCA-cross-linked protein. If there is no difference between these spectra, then replace light source

\section{ANTICIPATED RESULTS}

\section{Analytical data}

2-acetylamino-5-aminobenzenesulfonic acid (1)

Yield, 40\%; purity by ${ }^{1} \mathrm{H}$ NMR: greater than $97 \%$; HRMS-EI $\left(\mathrm{C}_{8} \mathrm{H}_{10} \mathrm{~N}_{2} \mathrm{O}_{4} \mathrm{~S}\right)$ calculated $(\mathrm{m} / \mathrm{z})$ 230.0361, observed $(\mathrm{m} / \mathrm{z}) 230.0365$; ${ }^{1} \mathrm{H}$ NMR $\left(499.849 \mathrm{MHz}, d_{6}\right.$-DMSO) $\delta 2.078\left(\mathrm{~s}, 3 \mathrm{H}, \mathrm{CH}_{3}\right), 7.30\left(\mathrm{dd}, \mathrm{J}=2.65 \mathrm{~Hz} ; 8.75 \mathrm{~Hz}, 1 \mathrm{H}, \mathrm{H}_{\mathrm{b}}\right), 7.70\left(\mathrm{~d}, \mathrm{~J}=2.65 \mathrm{~Hz} ; 1 \mathrm{H}, \mathrm{H}_{\mathrm{a}}\right), 8.39$ $\left(\mathrm{d}, \mathrm{J}=8.72 \mathrm{~Hz}, 1 \mathrm{H}, \mathrm{H}_{\mathrm{c}}\right) 10.355(\mathrm{~s}, 1 \mathrm{H}, \mathrm{NH}){ }^{13} \mathrm{C} \mathrm{NMR}\left(125.698 \mathrm{MHz}, d_{6}\right.$-DMSO) $\delta 24.5\left(\mathrm{CH}_{3}\right), 120.2\left(\mathrm{CH}_{\mathrm{c}}\right), 121.3\left(\mathrm{CH}_{\mathrm{a}}\right), 123.8\left(\mathrm{CH}_{\mathrm{b}}\right)$, $124.9\left(\mathrm{C}_{\mathrm{NH} 2}\right), 134.4\left(\mathrm{C}_{\mathrm{S} 03 \mathrm{H}}\right), 135.6\left(\mathrm{C}_{\text {acetamido }}\right), 167.3\left(\mathrm{C}_{(0)}\right)$.

\section{Sodium 3, $3^{\prime}$-bis(sulfonato)-4,4'-bis (acetamido) azobenzene (2)}

Yield, 15\%; purity by ${ }^{1} \mathrm{H}$ NMR: greater than $97 \%$; HRMS-ESI $\left(\mathrm{C}_{16} \mathrm{H}_{14} \mathrm{~N}_{4} \mathrm{O}_{8} \mathrm{~S}_{2}\right)$ calculated $(\mathrm{m} / \mathrm{z})$ 455.0336, observed $(\mathrm{m} / \mathrm{z})$ 455.0318; ${ }^{1} \mathrm{H}$ NMR (499.849 MHz, $d_{6}$-DMSO) $\delta 2.208\left(\mathrm{~s}, 3 \mathrm{H}, \mathrm{CH}_{3}\right), 7.794\left(\mathrm{dd}, J=2.36 \mathrm{~Hz} ; 8.74 \mathrm{~Hz}, 1 \mathrm{H}, \mathrm{H}_{\mathrm{b}}\right), 8.02\left(\mathrm{~d}, J=8.69 \mathrm{~Hz} ; 1 \mathrm{H}, \mathrm{H}_{\mathrm{c}}\right), 8.179$ 
$\left(\mathrm{d}, \mathrm{J}=2.34 \mathrm{~Hz}, 1 \mathrm{H}, \mathrm{H}_{\mathrm{a}}\right)^{13} \mathrm{C} \mathrm{NMR}\left(125.698 \mathrm{MHz}, \mathrm{d}_{6}\right.$-DMSO) $\delta 23.7\left(\mathrm{CH}_{3}\right), 121.9\left(\mathrm{CH}_{\mathrm{a}}\right), 124.2\left(\mathrm{CH}_{\mathrm{c}}\right), 125.9\left(\mathrm{CH}_{\mathrm{b}}\right), 133.82\left(\mathrm{C}_{\text {acetamido }}\right)$, $136.3\left(\mathrm{C}_{\mathrm{S} 03 \mathrm{H}}\right), 147.8\left(\mathrm{C}_{\mathrm{azo}}\right), 172.4\left(\mathrm{C}_{(0)}\right)$.

\section{Sodium 3,3'-bis(sulfonato)-4, 4'-bis(amino)azobenzene (3)}

Yield, $96 \%$; purity by ${ }^{1} \mathrm{H}$ NMR: greater than $98 \%$; HRMS-ESI $\left(\mathrm{C}_{12} \mathrm{H}_{10} \mathrm{~N}_{4} \mathrm{O}_{6} \mathrm{~S}_{2}\right)$ calculated $(\mathrm{m} / \mathrm{z}) 371.0125$, observed $(\mathrm{m} / \mathrm{z}) 371.0129 ;{ }^{1} \mathrm{H}$ $\operatorname{NMR}\left(499.849 \mathrm{MHz}, d_{6}\right.$-DMSO) $\delta 6.20\left(\mathrm{~s}, 2 \mathrm{H}, \mathrm{NH}_{2}\right), 6.71\left(\mathrm{~d}, \mathrm{~J}=8.60 \mathrm{~Hz}, 1 \mathrm{H}, \mathrm{H}_{\mathrm{c}}\right), 7.53\left(\mathrm{dd}, \mathrm{J}=2.31 \mathrm{~Hz} ; 8.65 \mathrm{~Hz}, 1 \mathrm{H}, \mathrm{H}_{\mathrm{b}}\right), 7.94(\mathrm{~d}, \mathrm{~J}=$ $\left.2.34 \mathrm{~Hz}, 1 \mathrm{H}, \mathrm{H}_{\mathrm{a}}\right)^{13} \mathrm{C}$ NMR $\left(125.698 \mathrm{MHz}, \mathrm{d}_{6}\right.$-DMSO) $\delta 115.1\left(\mathrm{CH}_{\mathrm{c}}\right), 121.3\left(\mathrm{CH}_{\mathrm{a}}\right), 124.5\left(\mathrm{CH}_{\mathrm{b}}\right), 129.6\left(\mathrm{C}_{\mathrm{SO} 0}{ }^{-}\right), 141.7\left(\mathrm{C}_{\mathrm{NH} 2}\right), 147.0\left(\mathrm{C}_{\mathrm{azo}}\right)$.

\section{BSBCA (4)}

Yield, 95\%; purity by ${ }^{1} \mathrm{H}$ NMR: greater than $97 \%$; HRMS-ESI $\left(\mathrm{C}_{16} \mathrm{H}_{14} \mathrm{Cl}_{2} \mathrm{~N}_{4} \mathrm{O}_{8} \mathrm{~S}_{2}\right)$ calculated $(\mathrm{m} / \mathrm{z}) 522.9557$, observed $(\mathrm{m} / \mathrm{z})$ $522.9560 ;{ }^{1} \mathrm{H}$ NMR $\left(499.849 \mathrm{MHz}, \mathrm{D}_{2} 0\right) \delta 4.42\left(\mathrm{~s}, 2 \mathrm{H}, \mathrm{CH}_{2}\right), 7.98\left(\mathrm{dd}, \mathrm{J}=2.41 \mathrm{~Hz} ; 8.86 \mathrm{~Hz}, 1 \mathrm{H}, \mathrm{H}_{\mathrm{b}}\right), 8.20(\mathrm{~d}, J=2.46 \mathrm{~Hz}, 1 \mathrm{H}$, $\left.\mathrm{H}_{\mathrm{a}}\right), 8.53\left(\mathrm{~d}, J=8.82 \mathrm{~Hz}, 1 \mathrm{H}, \mathrm{H}_{\mathrm{c}}\right), 11.23(\mathrm{~s}, 1 \mathrm{H}, \mathrm{NH}){ }^{13} \mathrm{C}$ NMR $\left(125.698 \mathrm{MHz}, \mathrm{d}_{6}-\mathrm{D}_{2} 0\right) \delta 42.9\left(\mathrm{CH}_{2}\right), 119.0\left(\mathrm{CH}_{\mathrm{a}}\right), 119.9\left(\mathrm{CH}_{\mathrm{c}}\right)$, $125.7\left(\mathrm{CH}_{\mathrm{b}}\right), 135.8\left(\mathrm{C}_{\text {chloroacetamido }}\right), 136.5\left(\mathrm{C}_{\mathrm{SO} 03 \mathrm{H}}\right), 146.8\left(\mathrm{C}_{\mathrm{azo}}\right), 164.9\left(\mathrm{C}_{(0)}\right)$.

\section{Protein cross-linking}

The cross-linking reaction should proceed with an anticipated yield of more than $65 \%$ based on more than $98 \%$ cross-linking efficiency and more than $93 \%$ retention per pass on the Amicon ultra-15 centrifugal filters under the conditions specified. The MALDI or ESI $m / z$ of cross-linked protein, when compared with un-cross-linked protein, should yield a mass difference of approximately 452.5 Da. Figure 3 shows ESI mass spectra before and after reaction of a GCN4 protein with BSBCA.

UV-visible spectroscopy is typically employed to measure the degree of trans-to-cis isomerization in the cross-linked protein after irradiation (Fig. 4). For a BSBCA cross-linked protein in its thermally stable trans configuration, the UV-visible spectrum should show a strong maximum at $363 \mathrm{~nm}$, which is typical for amide-substituted azobenzene $\pi-\pi^{*}$ transitions. Irradiation with light at a wavelength of $370 \mathrm{~nm}$ will lead to the loss of that absorption maximum along with a slight increase in absorbance at $450 \mathrm{~nm}$, corresponding to the $n-\pi^{*}$ transition of cis-azobenzene. Thermal reversion from the cis-to-trans state typically proceeds over a range of half-lives $\left(10-30 \mathrm{~min}\right.$ at $\left.25^{\circ} \mathrm{C}\right)$ depending on the protein that has been cross-linked and the residue spacing spanning the cross-link.

CD spectroscopy can be used to gauge the degree of helix-coil transition brought about by irradiation (Fig. 5). For $i-i+11$ cross-linked $\alpha$-helices, which are compatible with the thermally stable trans configuration of BSBCA, the CD spectrum should exhibit weaker molar ellipticity at $222 \mathrm{~nm}$ upon irradiation at $360 \mathrm{~nm}$. This indicates that trans-to-cis photo-isomerization is coupled to helix unfolding within these proteins. In contrast, $i-i+7$ and $i-i+4$ cross-linked $\alpha$-helices are compatible with the cis BSBCA configuration and should exhibit stronger molar ellipticity at $222 \mathrm{~nm}$ upon sample irradiation at $370 \mathrm{~nm}$. Thus, an increase in helix content is coupled to trans-to-cis photo-isomerization within these proteins.

ACKNOWLEDGMENTS This work was supported by the Natural Sciences and Engineering Research Council of Canada and the Canadian Institutes of Health Research Training Program on Protein Folding.

COMPETING INTERESTS STATEMENT The authors declare that they have no competing financial interests.

Published online at http://www.natureprotocols.com

Reprints and permissions information is available online at http://npg.nature.com/ reprintsandpermissions

1. Renner, C. \& Moroder, L. Azobenzene as a conformational switch on model peptides. Chembiochem 7, 868-878 (2006).

2. Ulysse, L., Cubillos, J. \& Chmielewski, J. Photoregulation of cyclic peptide conformation. J. Am. Chem. Soc. 117, 8466-8467 (1995).

3. Kumita, J.R., Smart, 0.S. \& Woolley, G.A. Photo-control of helix content in a short peptide. Proc. Natl. Acad. Sci. USA 97, 3803-3808 (2000).

4. Bose, M., Groff, D., Xie, J.M., Brustad, E. \& Schultz, P.G. The incorporation of a photoisomerizable amino acid into proteins in E.coli. J. Am. Chem. Soc. 128, 388-389 (2006).

5. Muranaka, N., Hohsaka, T. \& Sisido, M. Photoswitching of peroxidase activity by position-specific incorporation of a photoisomerizable non-natural amino acid into horseradish peroxidase. FEBS Lett. 510, 10-12 (2002).

6. Nakayama, K., Endo, M. \& Majima, T. A hydrophilic azobenzene-bearing amino acid for photochemical control of a restriction enzyme BamHI. Bioconjugate Chem. 16, 1360-1366 (2005).

7. James, D.A., Burns, D.C. \& Woolley, G.A. Kinetic characterization of ribonuclease $S$ mutants containing photoisomerizable phenylazophenylalanine residues. Protein Eng. 14, 983-991 (2001).
8. Tang, X.J. \& Dmochowski, I.J. Controlling RNA digestion by RNase $\mathrm{H}$ with a light-activated DNA hairpin. Angew. Chem. Int. Ed. 45, 3523-3526 (2006).

9. Liu, Y. \& Sen, D. Light-regulated catalysis by an RNA-cleaving deoxyribozyme. J. Mol. Biol. 341, 887-892 (2004).

10. Borisenko, V., Burns, D.C., Zhang, Z. \& Woolley, G.A. Optical switching of ion-dipole interactions in a gramicidin channel analogue. J. Am. Chem. Soc. 122 6364-6370 (2000).

11. Volgraf, M. et al. Allosteric control of an ionotropic glutamate receptor with an optical switch. Nat. Chem. Biol. 2, 47-52 (2006).

12. Asanuma, H., Ito, T. \& Komiyama, M. Photo-responsive oligonucleotides carrying azobenzene in the side-chains. Tet. Lett. 39, 9015-9018 (1998).

13. Willner, I., Rubin, S. \& Riklin, A. Photoregulation of papain activity through anchoring photochromic azo groups to the enzyme backbone. J. Am. Chem. Soc. 113, 3321-3325 (1990).

14. Muramatsu, S., Kinbara, K., Taguchi, H., Ishii, N. \& Aida, T. Semibiological molecular machine with an implemented 'AND' logic gate for regulation of protein folding. J. Am. Chem. Soc. 128, 3764-3769 (2006).

15. Kumita, J.R., Flint, D.G., Smart, 0.S. \& Woolley, G.A. Photo-control of peptide helix content by an azobenzene cross-linker: steric interactions with underlying residues are not critical. Protein Eng. 15, 561-569 (2002).

16. Burns, D.C. et al. Origins of helix-coil switching in a light-sensitive peptide. Biochemistry 43, 15329-15338 (2004).

17. Woolley, G.A. Photo-controlling peptide $\alpha$ helices. Acc. Chem. Res. 38, 486-493 (2005).

18. Tyagi, R. \& Gupta, M.N. Chemical modification and chemical cross-linking for protein/enzyme stabilization. Biochemistry (Mosc.) 63, 334-344 (1998).

19. Wong, S.S. \& Wong, L.J.C. Chemical cross-linking and the stabilization of proteins and enzymes. Enzyme Microb. Technol. 14, 866-874 (1992). 
20. Borisenko, V. \& Woolley, G.A. Reversibility of conformational switching in light-sensitive peptides. J. Photochem. Photobiol. A-Chem. 173, 21-28 (2005).

21. Pozhidaeva, N., Cormier, M.E., Chaudhari, A. \& Woolley, G.A. Reversible photocontrol of peptide helix content: adjusting thermal stability of the cis state. Bioconjugate Chem. 15, 1297-1303 (2004).

22. Chi, L., Sadovski, 0. \& Woolley, G.A. A blue-green absorbing cross-linker for rapid photoswitching of peptide helix content. Bioconjugate Chem. 17, 670-676 (2006).

23. Zhang, Z.H., Burns, D.C., Kumita, J.R., Smart, O.S. \& Woolley, G.A. A water-soluble azobenzene cross-linker for photocontrol of peptide conformation. Bioconjugate Chem. 14, 824-829 (2003).

24. Rau, H. Azo Compounds. In Photochroism: Molecules and Systems, Revised Edition (eds. Dürr, H. \& Bouas-Laurent, H.) 165-192 (Elsevier, Amsterdam, 2003).

25. Sporlein, S. et al. Ultrafast spectroscopy reveals subnanosecond peptide conformational dynamics and validates molecular dynamics simulation. Proc. Natl. Acad. Sci. USA 99, 7998-8002 (2002).
26. Bredenbeck, J., Helbing, J., Kumita, J.R., Woolley, G.A. \& Hamm, P. $\alpha$-Helix formation in a photoswitchable peptide tracked from picoseconds to microseconds by time-resolved IR spectroscopy. Proc. Natl. Acad. Sci. USA 102, 2379-2384 (2005).

27. Flint, D.G., Kumita, J.R., Smart, 0.S. \& Woolley, G.A. Using an azobenzene cross-linker to either increase or decrease peptide helix content upon trans-to-cis photoisomerization. Chem. Biol. 9, 391-397 (2002).

28. Gasteiger, E. et al. Protein Identification and Analysis Tools on the ExPASy Server. In The Proteomics Handbook (ed. Walker, J.M.) 571-607 (Humana Press, Hertfordshire, U.K.,2005).

29. Woolley, G.A. et al. Reversible photocontrol of DNA binding by a designed GCN4bZIP protein. Biochemistry 45, 6075-6084 (2006).

30. Guerrero, L., Smart, 0.S., Woolley, G.A. \& Allemann, R.K. Photocontrol of DNA binding specificity of a miniature engrailed homeodomain. J. Am. Chem. Soc. 127, 15624-15629 (2005).

31. Guerrero, L. et al. Photochemical regulation of DNA-binding specificity of MyoD. Angew. Chem. Int. Ed. 44, 7778-7782 (2005). 